\title{
Demography, Knowledge-Gap Effect and Exclusive Breastfeeding Campaign in Lagos and Ogun States, Nigeria
}

\author{
Kolade Ajilore ${ }^{1}$, Helen Ambassador-Brikins ${ }^{2} \&$ Kevin Onyenankeya ${ }^{3}$ \\ ${ }^{1}$ Department of Mass Communication, Babcock University, Illishan-Remo, Nigeria \\ ${ }^{2}$ Instructional Resources Development Unit, National Open University of Nigeria, Lagos, Nigeria \\ ${ }^{3}$ Department of Communication, University of Fort Hare, Alice, South Africa \\ Correspondence: Kevin Onyenankeya, Department of Communication, University of Fort Hare, King William's \\ Road, Alice, South Africa.
}

Received: September 13, 2017 Accepted: October 23, 2017 Online Published: November 20, 2017

doi:10.5539/gjhs.v9n12p176 URL: https://doi.org/10.5539/ gjhs.v9n12p176

\begin{abstract}
Resistance to six-months exclusive breastfeeding remains pervasive among mothers in spite of the numerous health and economic benefits of breastfeeding. Experts attribute the nonchalance towards exclusive breastfeeding to several factors, including myths and traditional beliefs as well as fear that breastfeeding weakens the breast fibre and consequently, quickens the sagging of the breast and the woman's sexual appeal. In Nigeria, government and non-governmental agencies continue to promote exclusive breastfeeding for the first six months of life. The purpose of this paper was to investigate the influence of socio-economic variables on the awareness, knowledge and adoption of the six months exclusive breastfeeding campaign in two Nigerian states.

A mixed methods design was employed. First, a series of in-depth interviews was conducted with six health care workers in Lagos and Ogun States. Thereafter, 1500 copies of a questionnaire containing16 items were administered to a purposively drawn sample of lactating mothers whose babies fell within the age range of 0 and 12 months.

The results showed a high awareness level of the six-months exclusive breastfeeding campaign. Chi Square test suggests that the socio economic status of women does not significantly influence their awareness of the six months exclusive breastfeeding ( $p>0.060)$. Similarly, respondents' educational levels showed no significant influence on their knowledge of six months exclusive breastfeeding $(p>0.070)$.

Contrary to the thesis of the knowledge gap communication theory, awareness does not depend on socio economic status. In all, demographics of women in Lagos and Ogun states do not influence their awareness, knowledge and adoption of six months exclusive breastfeeding.
\end{abstract}

Keywords: Socio-economic factors, knowledge, adoption, exclusive breastfeeding, Nigeria

\section{Introduction}

The practice of breastfeeding is natural to humans and other mammals. However, advocates of six months exclusive breastfeeding have perennially expressed concern over the seeming reluctance or outright refusal of mothers, to breastfeed in general, or to adhere to the recommendation of WHO/UNICEF to exclusively breastfeed their infants for the first six months of life (Ajayi, 2012). Some of the reasons attributed to the reluctance are myths and traditional beliefs opposed to breastfeeding (UNICEF, 2010; Umar \& Oche, 2013), the stress and struggle of keeping up with the recommended period of six months exclusive breastfeeding (Moisse, 2011), perceived insufficiency of breast milk, lack of social support to mothers and care givers (Agunbiade \& Ogunleye, 2012), work demands on mothers, and linking breastfeeding with the transmission of HIV (UNICEF, 2010). Other factors militating against the adoption of six months exclusive breastfeeding include: the notion in some medical circles that exclusive breastfeeding could lead to iron deficiency, food allergies and underdevelopment of taste in the infant (Moisse, 2011); inability of some states to properly enforce the international code prohibiting marketing of infant formula or breast milk substitutes(Cox, Gidlia, \& Binns, 2015); negative attitudes of mothers towards infant care (Mgongo et al., 2013); as well as the belief among some women that breastfeeding emasculates breast fibre and consequently, quickens the sagging of the breast and the woman's sexual appeal (Agunbiade \& Ogunleye, 2013). 
The six-months exclusive breastfeeding is highly advantageous to the mother, child and the society. National Breastfeeding Campaign carried out in the United States of America between 2004 and 2006, showed that babies who were fed breastmilk exclusively for six months had less chances of developing "ear infections, diarrhoea, respiratory illness", and also less likelihood of developing "childhood obesity" (Womenshealth.gov, 2011). Breast milk is readily available and easily digestible and contains the right quantities of fat, sugar, water and protein which the infant requires for growth. It also provides all the antibodies which the baby needs to be protected against illness. The chemical make-up of breast milk is such that it reduces the risk of conditions such as type 1 diabetes, childhood leukaemia, and the kind of skin rash known as atopic dermatitis. It also reduces the threat of "sudden infant death syndrome (SIDS)" (Womenshealth.gov, 2011). The Nigerian Institute of Journalism (NIJ, 1996) in a report endorsed by UNICEF, states that breast milk contains a laxative which helps the new-born to pass out the first stool, known as meconium. This action helps prevent jaundice, which, glucose water given to many new-borns, cannot do.

Exclusive breastfeeding gives all infants the opportunity of a good start in life, irrespective of their parents' socioeconomic status, as it ensures perfect nutrition for the baby. Again, breast milk perfectly meets the infant's nutritional needs, and even changes in composition to meet the child's needs as he grows. Hind milk, the milk which comes out later, contains fat which is needed for the baby's brain development (NIJ, 1996). WHO posits that, in addition to protecting the infant from infections and chronic diseases, exclusive breastfeeding promotes sensory and cognitive development in the baby. Breast milk is a unique source of nutrients to the infant and is irreplaceable (National Resources Defence Council (NRDC), 2005).

Breastfeeding also benefits the mother. The sucking action of the new-born helps to expel the placenta and reduce bleeding following delivery. Frequent breastfeeding can help remedy common breast problems such as engorgement and sore nipples, caused by poor attachment as or by poor positioning of the infant to the breast; and mastitis caused by insufficient emptying of the breast (NIJ, 1996). Breastfeeding helps women to lose weight since they burn calories during lactation (NRDC Online Newsletter, 2005). National Primary Health Care Development Agency (2011) reports that exclusive breastfeeding acts as a kind of family planning method as a woman who breastfeeds her baby exclusively can have about 98 percent protection from pregnancy provided her menstrual periods have not resumed. The NRDC Online Newsletter (2005) suggests that breastfeeding releases to the mother, oxycocin, a hormone that causes the uterus to quickly reverse to its regular size. Breastfeeding can diminish the likelihood of the mother developing certain adverse conditions in future. If the mother is diabetic, breastfeeding will promote her health. Women who breastfeed their babies are less prone to feelings of anxiety as the process enhances their emotional health. They develop emotional ties with their babies. Breastfeeding helps to establish the relationship between mother and child in much later years. Besides, a woman's knowledge that she is able to provide all the nutrients required by her baby gives her a sense of confidence.

Breastfeeding is actually, the cheapest way of feeding the baby. Apart from not having to spend money on formula, breastfeeding helps reduce health care costs for babies as breastfed babies fall sick less often than those who are not breastfed. Work becomes less and easier for mothers as they would not need to sterilise bottles and mix and warm formula. Exclusive breastfeeding is better for the environment as less refuse from plastic bottles and formula cans is generated. (Womenshealth.gov, 2011).

UNICEF (2005) links breastfeeding to infants' fundamental human rights, insisting that, "Breastfeeding is at the intersection of many human rights that are addressed in many international rights conventions." Ajayi (2012) notes that virtually all mothers can breastfeed their infants if they have accurate information about the benefits of breastfeeding and if they are given support by their families, communities and the healthcare system. Many societies still cling to myths about breastfeeding, and so communication efforts should be channelled towards researching and addressing them (UNICEF, 2010). Examples of such myths are: that colostrum is dirty and should therefore, be thrown away; that babies need water, teas and herbal extracts in addition to breast milk; that nursing mothers who are angry or afraid should not breastfeed. Ajilore, Atakiti and Onyenankeya (2017) hold that targeted communication could be an effective instrument in dispelling strongly held myths or beliefs.

In spite of the numerous benefits of exclusive breastfeeding, compliance worldwide has been poor. According to UNICEF (2013) report, "Only 39 per cent of children aged less than six months were exclusively breastfed in 2012." despite the fact that "breastfeeding is the cheapest and most cost effective life saver in history". Nigeria's Federal Ministry of Health puts the rate of compliance in Nigeria at 13\%. In 2008 the Lancet Series on Maternal and Child Malnutrition as cited in Aryeetey and Goh (2013) reported that suboptimal breastfeeding accounted for 12 per cent of the deaths of children under the age of five. The authors observe that suboptimal feeding remains prevalent, especially in developing countries, with both short and long term effects on the well-being of children. 
UNICEF (2006) maintains that exclusive breastfeeding for the first six months of infant life could help prevent about 13 percent of deaths of children under the age of five in over 42 countries. According to UNICEF (2006) exclusive breastfeeding was a more potent preventive measure against mortality among children under the age of five years as more than 3,500 infant deaths could be prevented every day with optimal breastfeeding.

Although breastfeeding seems intuitive, it can also be cultivated (UNICEF (2015). Therefore creating an enabling environment for it to become the norm is important (UNICEF, 2013).) Studies have demonstrated that mothers require support from their families, communities, health systems and even in the work place in order to establish and sustain optimum breastfeeding. Perhaps ignorance of its benefits and other human factors have prevented some women from feeding their babies exclusively on breast milk for the first six months after birth. Ever since the 1990 Innocenti Declaration on the Protection, Promotion and Support of Breastfeeding (UNICEF, 2006), many countries have rolled out various communication campaigns to promote exclusive breastfeeding. Nigeria is one of the countries where six-month exclusive breastfeeding is regarded as an important public health issue because of the benefit it offers. The Federal Ministry of Health (FMOH, 2010) through the "National Policy on Infant and Young Child Feeding (IYCF)" considers six months exclusive breastfeeding the foundation for adequate infant and young child nutrition and is committed to the promotion of exclusive breastfeeding for the first six months of a child's life. "The overall goal of the National Policy on Infant and Young Child Feeding in Nigeria is to ensure optimal growth, protection and development of the Nigerian child from birth to the first five years of life" (FMOH, 2010:4). Considering the importance attached to exclusive breastfeeding, it is imperative to find out if the campaign for six months exclusive breastfeeding reached women on different socio-economic strata, and whether it influenced them to adopt the practice.

\subsection{Purpose}

Empirical evidence attests to the fact that in addition to individual and stimulus variables, situational factors also determine human perception and attitude (Hawkins, Best, \& Coney, 1995; Arnold, Price, \& Zinkhan, 2002; Schiffman \& Kanuk, 2007). In most cases, these contextual factors interact with personal and stimulus factors to determine the success of any intervention programme. In the analysis of Benjamin (1997), people's geographic location and residence make a significant difference in their perception, and consequently their response to stimuli. This observation also resonates with Fill (2009), who observes that the income, age, gender, and educational attainment of people significantly influence their propensity and susceptibility to any stimuli.

Tichenor, Donohue and Olien's (1970) Knowledge Gap Theory as cited in Baran and Davis (2011), hypothesizes that mass media messages reach people of higher socio-economic status faster and more easily than those of lower socio-economic status. The information-rich group consists of high status people who are educated and have access to the mass media, and are presumably, well informed. The information-poor fall within the lower socio-economic ladder, mainly because of lower educational levels and limited financial capacity leading to limited access to mass media. Straubhaar and LaRose (2000) hold that the media widens the knowledge gap even when its intention is actually to close it. Anaeto, Onabajo and Osifeso (2008) postulate that the knowledge gap thesis holds because people across the two bipolar classes have different communication skills due to their different levels of education, which in turn, affect, not only their reading, comprehension and memory capacity, but also the amount of previously acquired information as well as different structures of social contacts. Against the backdrop of the objective of the six months exclusive breastfeeding campaign, and the thesis of the knowledge gap theory, this study was designed to determine the influence of socio-economic variables on the campaign.

\subsection{Research Hypotheses}

The following hypotheses were tested:

$\mathbf{H}_{\mathbf{O}}$ 1: The socio-economic status of women does not significantly influence their awareness of the six months exclusive breastfeeding campaign.

$\mathbf{H}_{\mathbf{O}}$ 2: The educational levels of women do not significantly influence their knowledge of the six months exclusive breastfeeding campaign.

$\mathbf{H}_{\mathbf{O}} 3$ : Settlement patterns of women (urban areas versus rural areas) do not significantly influence their adoption of six months exclusive breastfeeding.

\subsection{Area Description}

The study covers public health centres in 12 local governments randomly selected from Lagos and Ogun States, South West Nigeria. Lagos was chosen because it featured all the characteristics of the research interest. Because of its cosmopolitan nature, it enjoys a concentration of media houses and benefited directly from the programmes 
of many government and non-governmental bodies. It also has areas considered rural by modern standards. Ogun State, a coaxial state, was also selected because it also embodied some of the characteristics of interest to the study. Its contiguity to Lagos State may have affected its pace of development.

\section{Methods}

\subsection{Procedure}

The participants of the study were drawn purposively from lactating mothers whose babies fell within the age range of 0 and 12 months, who visited public health centres in the selected 12 local governments. The attendance lists were used as sampling frames. In all, 1500 copies of a 16 item questionnaire were personally administered to respondents. Prior to the main research, a series of in-depth interviews was conducted with health care workers in Lagos and Ogun States to establish the mechanism and modus operandi of the six months exclusive breastfeeding campaign in these two states.

Health workers, such as nurses, nutritionists and community health workers constitute the fulcrum of the campaign. These health workers give "health talks" to pregnant women and nursing mothers who attend state owned primary health care centres and secondary health facilities to receive prenatal care and immunisation of their children respectively. The health talks comprise education on critical household safety measures and practices including six months exclusive breastfeeding. Health workers usually urge mothers to breastfeed their babies within the first 30 minutes after delivery and upon demand. When mothers and their babies are eventually discharged from the maternity centres, members of the community support groups, who are members of the social mobilisation teams, are notified so that they can forestall any relapse on the part of the nursing mothers.

Trained social mobilisers work with health educators to organise motorised on-the-road campaigns designed to take the message to the door-step of the target public. The message on six months exclusive breastfeeding is delivered to the accompaniment of live music provided by hired musicians. These itinerant health educators concentrate on places where the majority of the predetermined target population can be easily reached such as mechanic villages, army barracks, market places, and bus stops. Furthermore, press briefing and media coverage are organised to further publicise breastfeeding and create platforms for extensive discussion on the theme of the programme. This is also reinforced with radio jingles promoting the theme.

In the second phase, the researchers first identified and listed all the local governments in each of the two states- 20 local governments in each. The list of local governments was then stratified first by state and then by urban/rural dichotomy. From these four sub-categories, 12 local governments were randomly selected using the fishbowl technique. From urban Lagos; Agege, Etiosa and Shomolu local governments emerged, while Epe, Ibeju Lekki and Ikorodu local governments were selected for rural Lagos. In the case of Ogun State; Sagamu, Ado-odo Ota and Abeokuta local governments emanated from urban Ogun State sub-category while Remo North, Yewa North and Ewekoro local governments represented rural Ogun State.

The researchers then approached the headquarters of each of the chosen local governments for the lists and addresses of the public health centres domiciled within its jurisdiction. This approach was considered critical to the successful execution of the study as the Innocenti Declaration on the Promotion, Protection and Support of Breastfeeding mainly depends on government to promote six months exclusive breastfeeding. The health centres are well visited by mothers who attended immunisation and infant welfare clinics with their babies.

\subsection{Analysis}

Data were analysed using SPSS and presented as simple frequencies and cross tabulations. SPSS was used to analyse participants' demographics, awareness, knowledge and adoption of six-month exclusive breastfeeding. Chi Square analysis was used to test the relationship between income, educational attainment and settlement and awareness, knowledge and adoption of exclusive breastfeeding.

\section{Results}

\subsection{Demographic Distribution of Respondents}

As shown in Table 1, the majority of respondents (17.4\%) were located in Ado Odo Ota. This was followed by those from Ikorodu (14.2\%) and Agege (13.3\%). Ewekoro (1.9\%) and Remo North $(2.0 \%)$ had the lowest population. The majority of respondents were between the ages of 25 and 29 (29.6\%). Respondents between 15 and 19 years accounted for $4.5 \%$ while respondents who were below 15 years accounted for $1.2 \%$. About a third of the respondents did not go beyond senior secondary school level (29.3\%). Those who never attended formal school accounted for $10.1 \%$. Respondents' marital status indicated that about 9 out of 10 or $92.6 \%$ were married. Nearly $4 \%$ of the respondents were single even though they were already nursing babies. 
The majority of the respondents (63.5\%) practised Christianity, followed by those who practised Islam (31.9\%). About two thirds of the respondents (64\%), were Yoruba followed by those of Igbo extraction (18.7\%). The occupational status of respondents showed that the majority (38.4\%) of the mothers had their own businesses while $18.9 \%$ of them engaged in petty trading. About $16.7 \%$ of them were in paid-employment and $15.3 \%$ were full-time housewives. With regards to income, the results showed that the majority of respondents (38.10\%) earned less than $\mathrm{N} 18,000.00$ monthly while only $1.60 \%$ earned above N250, 000.00 monthly.

Table 1. Respondents' Demographic Profile

\begin{tabular}{|c|c|c|c|}
\hline Variables & Categories & Frequency & $\%$ \\
\hline \multirow[t]{12}{*}{ LOCATION } & ABEOKUTA SOUTH & 116 & 8.2 \\
\hline & AGEGE & 186 & 13.3 \\
\hline & EPE & 76 & 5.4 \\
\hline & ETI OSA & 108 & 7.6 \\
\hline & EWEKORO & 26 & 1.9 \\
\hline & IBEJU LEKKI & 53 & 3.7 \\
\hline & IKORODU & 200 & 14.2 \\
\hline & ADO ODO OTTA & 248 & 17.4 \\
\hline & REMO NORTH & 28 & 2.0 \\
\hline & SAGAMU & 116 & 8.3 \\
\hline & SOMUOLU & 167 & 11.8 \\
\hline & YEWA NORTH & 86 & 6.2 \\
\hline \multirow[t]{8}{*}{ INCOME } & BELOW 18,000 & 531 & 37.8 \\
\hline & $18,000-50,000$ & 476 & 33.9 \\
\hline & $51,000-100,000$ & 73 & 5.2 \\
\hline & $101,000-150,00$ & 11 & .8 \\
\hline & $151,000-200,000$ & 11 & .8 \\
\hline & $201,000-250,000$ & 8 & .6 \\
\hline & ABOVE 250,000 & 21 & 1.5 \\
\hline & NO RESPONSE & 274 & 19.4 \\
\hline \multirow[t]{9}{*}{ AGE } & LESS THAN 15 YEARS & 17 & 1.2 \\
\hline & 15-19 YEARS & 63 & 4.5 \\
\hline & 20-24 YEARS & 260 & 18.5 \\
\hline & 25-29 YEARS & 416 & 29.5 \\
\hline & 30-34 YEARS & 406 & 28.9 \\
\hline & 35-39 YEARS & 180 & 12.8 \\
\hline & 40-44 YEARS & 25 & 1.8 \\
\hline & 45-49 YEARS & 11 & .8 \\
\hline & NO RESPONSE & 27 & 2.0 \\
\hline \multirow[t]{5}{*}{ EDUCATION } & NEVER ATTENDED SCHOOL & 142 & 10.1 \\
\hline & PRIMARY SCHOOL & 146 & 10.4 \\
\hline & JSS & 136 & 9.7 \\
\hline & SSS/GCE/TTC & 412 & 29.3 \\
\hline & NCE/OND & 298 & 21.2 \\
\hline
\end{tabular}




\begin{tabular}{|c|c|c|c|}
\hline & HND/B.A/B.SC & 208 & 14.8 \\
\hline & M.A/M.SC/EQUIVALENT & 25 & 1.8 \\
\hline & M.PHIL/PH.D & 1 & .1 \\
\hline & PROFESSIONAL QUALIFICATION & 11 & .8 \\
\hline & OTHER & 1 & .1 \\
\hline & NO RESPONSE & 25 & 1.5 \\
\hline \multirow[t]{5}{*}{ MARITAL STATUS } & MARRIED & 1301 & 92.6 \\
\hline & SINGLE & 54 & 3.9 \\
\hline & DIVORCED & 14 & 1.0 \\
\hline & WIDOWED & 6 & .4 \\
\hline & NO RESPONSE & 30 & 2.1 \\
\hline \multirow[t]{5}{*}{ RELIGION } & CHRISTIANITY & 892 & 63.5 \\
\hline & ISLAM & 448 & 31.9 \\
\hline & ATR & 24 & 1.7 \\
\hline & OTHER & 6 & .4 \\
\hline & NO RESPONSE & 35 & 2.5 \\
\hline \multirow[t]{5}{*}{ ETHNICITY } & HAUSA & 98 & 7.0 \\
\hline & IGBO & 263 & 18.7 \\
\hline & YORUBA & 899 & 64.0 \\
\hline & OTHER & 118 & 8.4 \\
\hline & NO RESPONSE & 27 & 2.0 \\
\hline \multirow[t]{6}{*}{ OCCUPATION } & A FULL TIME HOUSE WIFE & 215 & 15.3 \\
\hline & A BUSINESS WOMAN & 540 & 38.4 \\
\hline & IN PAID EMPLOYMENT & 235 & 16.7 \\
\hline & A JOB SEEKER & 100 & 6.9 \\
\hline & A PETTY TRADER & 266 & 18.9 \\
\hline & NO RESPONSE & 49 & 3.7 \\
\hline TOTAL & TOTAL & 1405 & 100 \\
\hline
\end{tabular}

\subsection{Awareness, Knowledge and Practice of Exclusive Breastfeeding}

Table 2 shows that nearly $95 \%$ of respondents are aware of the six-month exclusive breastfeeding campaign. Interpersonal channels emerged as the most popular sources of exposure to the exclusive breastfeeding campaign. Health workers at the ante-natal clinic were rated highest (56.5\%) in creating awareness and building knowledge about exclusive breastfeeding, followed by health workers at the child welfare clinic $(38.6 \%)$, then television $(34.7 \%)$ and radio $(27.8 \%)$, respectively. A close examination of the responses revealed that health workers in both prenatal and immunisation clinics served as a source of exposure of the campaign to $95.1 \%$ of respondents, while the conventional mass media channels such as television, radio, books, newspapers and magazines were a source of exposure to $80.6 \%$ of respondents. About nine per cent $(8.8 \%)$ of the respondents indicated that new media served as their source of exposure.

About $73 \%$ of the respondents affirmed that a baby below the age of six months was supposed to be exclusively fed on breast milk. This suggests that the majority of the respondents have adequate knowledge of exclusive breastfeeding. Nearly $45 \%$ of respondents stated that they had practised exclusive breastfeeding for more than six months while $12.6 \%$ said they had practised it for less than one month. Only $6.4 \%$ of respondents stated that they never practised exclusive breastfeeding. When asked what influenced their decision to practice exclusive breastfeeding, the majority of respondents cited the information and counselling from the health workers at the prenatal clinics (46.8\%) and immunisation clinics (25.9\%). The mass media's role was insignificant as only 3.3\% 
attributed influence to adhere to the practice to information from the media.

Table 2. Composite Table of Responses to Items Testing Awareness, Knowledge and Practice of Campaign Theme

\begin{tabular}{|c|c|c|c|}
\hline Variables & Categories & $\mathrm{Fx}$ & $\%$ \\
\hline \multirow{3}{*}{$\begin{array}{l}\text { Familiarity with campaign } \\
\text { theme }\end{array}$} & Recall & 1330 & 94.7 \\
\hline & Non-recall & 63 & 4.5 \\
\hline & Not sure & 12 & 0.8 \\
\hline \multirow{17}{*}{$\begin{array}{l}\text { Means of exposure to } \\
\text { campaign messages }\end{array}$} & Books & 112 & 7.9 \\
\hline & Magazine & 70 & 4.9 \\
\hline & Newspaper & 75 & 5.3 \\
\hline & Poster/handbills & 45 & 3.2 \\
\hline & Billboards along the road & 47 & 3.3 \\
\hline & Radio & 397 & 27.8 \\
\hline & Television & 495 & 34.7 \\
\hline & The internet & 125 & 8.8 \\
\hline & Health workers at ante-natal clinic & 805 & 56.5 \\
\hline & Health workers at child welfare clinic & 551 & 38.6 \\
\hline & Ante-natal clinic card/booklet & 219 & 15.4 \\
\hline & Immunisation card/booklet & 203 & 14.2 \\
\hline & Community announcement & 54 & 3.8 \\
\hline & Family members & 136 & 9.5 \\
\hline & Friends & 120 & 8.4 \\
\hline & Religious leaders & 69 & 8.4 \\
\hline & others & 15 & 1.1 \\
\hline \multirow{4}{*}{$\begin{array}{l}\text { Interpretation of campaign } \\
\text { messages }\end{array}$} & $\begin{array}{l}\text { A mother is free to introduce things like baby milk and water to her baby } \\
\text { anytime }\end{array}$ & 250 & 17.8 \\
\hline & All babies aged 0-6 months need herbs to be healthy & 58 & 4.2 \\
\hline & A baby who is not up to six months should be given only breast milk & 1025 & 73.0 \\
\hline & $\begin{array}{l}\text { A baby who is not up to six months should be given water because water } \\
\text { is important to life }\end{array}$ & 72 & 5.1 \\
\hline \multirow{7}{*}{$\begin{array}{l}\text { Duration of practice of } \\
\text { exclusive breastfeeding }\end{array}$} & Never & 90 & 6.4 \\
\hline & Less than one month & 177 & 12.6 \\
\hline & Between one and two months & 143 & 10.2 \\
\hline & Between three and four months & 148 & 10.5 \\
\hline & Between five and six months & 160 & 11.4 \\
\hline & Above six months & 622 & 44.3 \\
\hline & No response & 65 & 4.6 \\
\hline \multirow{4}{*}{$\begin{array}{l}\text { Influence behind adoption of } \\
\text { exclusive breastfeeding }\end{array}$} & Medical workers at the ante-natal clinic & 658 & 46.8 \\
\hline & Medical workers at the child welfare/immunisation clinic & 364 & 25.9 \\
\hline & Family members & 41 & 2.9 \\
\hline & Cultural beliefs and practice & 22 & 1.6 \\
\hline
\end{tabular}




\begin{tabular}{llll}
\hline & \multicolumn{1}{l}{ Your community leaders } & 8 & 0.6 \\
\cline { 2 - 4 } & Religious leaders & 11 & 0.8 \\
\cline { 2 - 4 } & The mass media & 46 & 3.3 \\
\cline { 2 - 4 } & Read about it on ante-natal card/booklet & 25 & 1.8 \\
\cline { 2 - 4 } & Saw the effect on other babies at the health center & 77 & 5.5 \\
\cline { 2 - 4 } & Read about it on baby's immunisation card/booklet & 21 & 1.5 \\
\cline { 2 - 4 } & Want baby to win the prize during competition & 10 & 0.7 \\
\cline { 2 - 4 } & No response & 122 & 8.6 \\
\hline TOTAL & & 1405 & 100 \\
\hline
\end{tabular}

\subsection{Test of Hypothesis}

\subsubsection{Hypothesis 1}

Ho. The socio economic status of women does not significantly influence their awareness of the six months exclusive breastfeeding campaign.

A cross tabulation of an independent and a dependent variables was done to ascertain the relationship between income and awareness of the campaign. Data showed a high awareness level along all income categories. However, not all income categories had exactly the same awareness levels. As shown in Table 3 the awareness level appeared to rise as the income increases. For instance, $95.7 \%$ of respondents who earned incomes less than N18,000.00 monthly were aware of the campaign for exclusive breastfeeding while almost everyone between the income bracket of N101,000.00-N150,000.00 indicated awareness of the exclusive breastfeeding campaign. The Chi Square test suggest that the socio economic status of women does not significantly influence their awareness of six months exclusive breastfeeding $(\mathrm{p}>0.060)$. This indicates that awareness of six months exclusive breastfeeding does not depend on income level (See Table 4).

Table 3. Relationship between the Socio-economic Status of Respondents and their Awareness of Six-month Exclusive Breastfeeding

\begin{tabular}{|c|c|c|c|c|c|c|c|}
\hline 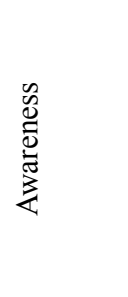 & $\begin{array}{l}8 \\
\infty \\
\infty \\
z \\
z \\
0 \\
\infty\end{array}$ & 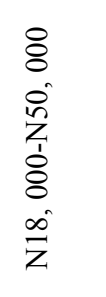 & 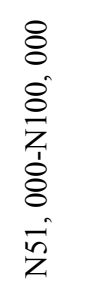 & 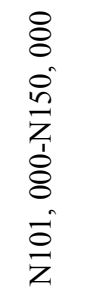 & 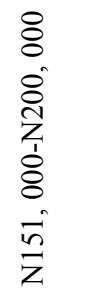 & 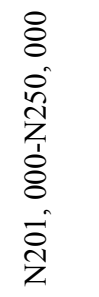 & 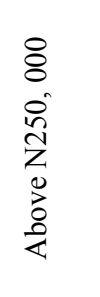 \\
\hline Yes & $95.7 \%$ & $95.4 \%$ & $97.3 \%$ & $100 \%$ & $100 \%$ & $62.5 \%$ & $90.9 \%$ \\
\hline No & $4.1 \%$ & $3.3 \%$ & $2.7 \%$ & 0 & 0 & $37.5 \%$ & $9.1 \%$ \\
\hline Not sure & $0.2 \%$ & $1.4 \%$ & 0 & 0 & 0 & 0 & 0 \\
\hline Total & $100 \%$ & $100 \%$ & $100 \%$ & $100 \%$ & $100 \%$ & $100 \%$ & $100 \%$ \\
\hline $\mathrm{n}$ & 536 & 469 & 73 & 12 & 11 & 8 & 22 \\
\hline
\end{tabular}

Table 4. Chi-Square Tests

\begin{tabular}{llll}
\hline & Value & df & Asymp. Sig. (2-sided) \\
\hline Pearson Chi-Square & $32.115^{\mathrm{a}}$ & 12 & .060 \\
Likelihood Ratio & 18.767 & 12 & .094 \\
Linear-by-Linear Association & 2.050 & 1 & .152 \\
N of Valid Cases & 1405 & & \\
\hline
\end{tabular}

${ }^{\mathrm{a}} 12$ cells $(57.1 \%)$ have expected count less than 5. The minimum expected count is .05 . 


\subsubsection{Hypothesis 2}

Ho. The educational levels of women do not significantly influence their knowledge of the six months exclusive breastfeeding campaign.

Similarly, a cross tabulation was carried out to ascertain the relationship between respondents' educational status and knowledge of the six months exclusive breastfeeding campaign. Table 5 shows that there was knowledge of what the concept means across all the educational categories. More than $74 \%$ of respondents with formal education displayed adequate knowledge of exclusive breastfeeding. Respondents with higher levels of education recorded a relatively higher knowledge of the concept of exclusive breastfeeding. But as the Chi-Square Test (Table 6) showed the educational levels of women do not significantly influence their knowledge of six months exclusive breastfeeding ( $p>0.07$ ), meaning that knowledge of six months exclusive breastfeeding does not depend on the level of education attained.

Table 5. Relationship between the Educational Levels of Respondents and their Knowledge of Six Months Exclusive Breastfeeding

\begin{tabular}{|c|c|c|c|c|c|c|c|c|c|c|}
\hline 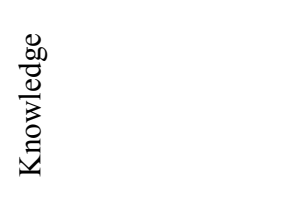 & 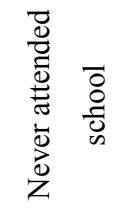 & $\begin{array}{l}\overrightarrow{8} \\
0 \\
\overline{0} \\
\infty \\
\vec{\Xi} \\
\vec{\Xi} \\
\vec{\Xi}\end{array}$ & $\tilde{N}$ & $\begin{array}{l}\vec{E} \\
\vec{E} \\
\overline{0} \\
\ddot{D} \\
\mathscr{n}\end{array}$ & 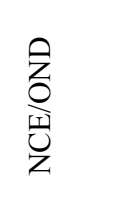 & 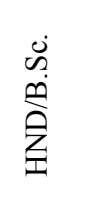 & $\sum_{i}^{\infty}$ & 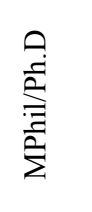 & $\begin{array}{l}\bar{\Xi} \\
\stackrel{0}{0} \\
0 \\
0 \\
0 \\
0 \\
0\end{array}$ & $\begin{array}{l}\bar{\Xi} \\
\bar{\Xi}\end{array}$ \\
\hline Baby milk and water & $10.3 \%$ & $8.8 \%$ & $24 \%$ & $15.6 \%$ & $23.1 \%$ & $12.3 \%$ & 0 & 0 & $16.7 \%$ & 0 \\
\hline Agbo & $10.3 \%$ & $4 \%$ & $3.1 \%$ & $7.5 \%$ & $3 \%$ & 0 & 0 & 0 & $8.3 \%$ & $50 \%$ \\
\hline Only breastmilk & $74.2 \%$ & $82.4 \%$ & $62 \%$ & 71.8 & $67.5 \%$ & $85.4 \%$ & $87.5 \%$ & $100 \%$ & $75 \%$ & $50 \%$ \\
\hline Only water & $5.2 \%$ & $4.8 \%$ & $10.9 \%$ & $5.1 \%$ & $6.3 \%$ & $2.3 \%$ & $12.5 \%$ & 0 & 0 & 0 \\
\hline Total & $100 \%$ & $100 \%$ & $100 \%$ & $100 \%$ & $100 \%$ & $100 \%$ & $100 \%$ & $100 \%$ & $100 \%$ & $100 \%$ \\
\hline $\mathrm{n}$ & 139 & 147 & 139 & 415 & 300 & 206 & 22 & 1 & 12 & 2 \\
\hline
\end{tabular}

Table 6. Chi-Square Tests

\begin{tabular}{llll}
\hline & Value & df & Asymp. Sig. (2-sided) \\
\hline Pearson Chi-Square & $74.980^{\mathrm{a}}$ & 27 & .007 \\
Likelihood Ratio & 77.931 & 27 & .000 \\
Linear-by-Linear Association & .718 & 1 & .397 \\
N of Valid Cases & 1405 & & \\
\hline
\end{tabular}

${ }^{\text {a }} 15$ cells $(37.5 \%)$ have expected count less than 5 . The minimum expected count is .05 .

\subsubsection{Hypothesis 3}

Ho. Settlement patterns (urban versus rural) of women do not significantly influence their adoption of six months exclusive breastfeeding.

As indicated in Table 7, the adoption of six months exclusive breastfeeding took the same pattern across the urban and rural settlements. In urban locations, $8.4 \%$ of respondents said they had never practised exclusive breastfeeding, $9.2 \%$ had practised it for less than one month, $4.7 \%$ for between one and two months, $12.6 \%$ for between three and four months, $10.8 \%$ for between five and six months and $54.2 \%$ beyond six months. Among rural dwellers, $4.6 \%$ of respondents indicated they had never breastfed their infants exclusively, $14.3 \%$ had breastfed exclusively for less than one month, $15.8 \%$ for between one and two months, $11 \%$ for between three and four months, $10.2 \%$ for between five and six months, and $44.1 \%$ beyond six months.

The Chi-Square Test (Table 8) produced P-Value 0.051 which means that the settlement patterns (urban versus rural) of women do not significantly influence their adoption of six months exclusive breastfeeding. This suggests where a woman lives has no bearing on her decision to adopt six months exclusive breastfeeding. 
Table 7. Relationship between Respondents' Settlement Patterns and their Adoption of the Six Months Exclusive Breastfeeding Campaign

\begin{tabular}{lll}
\hline Adoption & Urban & Rural \\
\hline Never & $8.4 \%$ & $4.6 \%$ \\
Less than one month & $9.2 \%$ & $14.3 \%$ \\
Between 1 and 2 months & $4.7 \%$ & $15.8 \%$ \\
Between 3 and 4 months & $12.6 \%$ & $11 \%$ \\
Between 5 and 6 months & $10.8 \%$ & $10.2 \%$ \\
Above 6 months & $54.2 \%$ & $44.1 \%$ \\
Total & $100 \%$ & $100 \%$ \\
$\mathrm{~N}$ & 936 & 469 \\
\hline
\end{tabular}

Table 8. Chi-Square Tests

\begin{tabular}{llll}
\hline & Value & df & Asymp. Sig. (2-sided) \\
\hline Chi-Square & $175.209^{\mathrm{a}}$ & 45 & .051 \\
Likelihood Ratio & 186.444 & 45 & .000 \\
N of Valid Cases & 1405 & & \\
\hline
\end{tabular}

${ }^{a} 12$ cells $(20.0 \%)$ have expected count less than 5 . The minimum expected count is 1.46 .

\section{Discussion}

The analysis of qualitative data from the first phase indicated that health officials promote exclusive breastfeeding to a large extent, as recommended by WHO/UNICEF, and as stipulated by the Federal Ministry of Health in the National Policy on Infant and Young Child Feeding in Nigeria. According to the Policy, efforts to promote feeding for infants and young children (which must have exclusive breastfeeding as the cornerstone) should involve; "creating awareness about optimal infant and young child feeding at all levels, employing social marketing strategies to address related issues at all levels of society", encouraging the involvement of communities in related activities, and utilising "notable events such as World Breastfeeding Week, Maternal and New-born and Child Health Week, Safe Motherhood Day, Day of the African Child and Micronutrient Day, to promote optimal infant and young child feeding in various states, local governments and communities" (FMOH, 2010: 22). The policy also recommends the development and dissemination of communication for behaviour and social change packages, and active involvement of "the media in all advocacy and social mobilisation for all the issues elaborated in this Policy" (FMOH, 2010: 22).

Most of the mothers claimed to have adopted exclusive breastfeeding. This claim to adoption of the practice did not depend on settlement patterns as it transcended both urban and rural areas. This is inconsistent with the submission of Benjamin (1997) that geographical location and residence affects perception and response to stimuli. In their examination of the offerings of McGuire's information processing theory, Anaeto et al. (2008) explain that an independent variable can positively or negatively influence any of the steps involved in processing information, eventually affecting the result of the persuasive effort.

Burton (2002) notes that different people can derive different meanings from one message due to certain factors such as the receivers' prejudices and beliefs. UNICEF (2010) is aware of how its efforts could be hindered by many factors such as myths and traditional beliefs.

The majority of mothers who patronise government owned primary healthcare centres were aware of the campaign for six months exclusive breastfeeding. Contrary to the thesis of the knowledge gap communication theory as propounded by Tichenor et al. (1970), awareness does not depend on socioeconomic status. There was no knowledge gap between high status respondents and those at the lower rungs. The majority of mothers understood messages on six months exclusive breastfeeding. Knowledge of six months exclusive breastfeeding did not depend on educational attainment, as a high level of knowledge of the concept was evident among all categories of educational attainment. There was no knowledge gap between those who were highly educated and those who were not. Respondents at all levels of educational attainment were information-rich regarding six months 
exclusive breastfeeding. Both rural and urban dwellers were information rich regarding six months exclusive breastfeeding. People of lower socioeconomic status were not disadvantaged. They, as well as those of high socioeconomic status, were information rich concerning the subject of the study. These findings are contrary to the suggestions by Fills (2009), that people's predilection to any stimuli is influenced by their demographics. The interpersonal efforts of the health workers in both the prenatal clinics and immunisation/infant welfare clinics had forestalled any gaps in information. Anaeto et al. (2008) note that homogeneous communities are likely to exhibit smaller knowledge gaps than heterogeneous communities especially when the homogeneous communities have informal but common communication channels. This study gives credence to this position as the primary health care centres were homogeneous communities; where all the respondents, irrespective of their socio-economic status, were there on immunisation days for one purpose. Moreover, the health workers served as the communication channels for all members of the community.

Respondents investigated were more or less members of a captive audience who willy-nilly, had to listen to messages by health workers promoting exclusive breastfeeding along with other health practices before they were allowed to attend to their primary purpose for being at the health facilities.

Given the pivotal role of interpersonal communication channels, as personified by health workers, to the relative success of the campaign; sustenance and possible reinforcement of this form of campaign strategy was plausible. The mass media should complement the efforts of interpersonal communication.

\section{Conclusion}

The findings of this study showed that there is high awareness of the six-month exclusive breastfeeding campaign and this cuts across all income categories. Respondents across socio-economic and educational status displayed adequate knowledge of the concept of the six-month exclusive breastfeeding. It can be concluded that knowledge and practice of exclusive breastfeeding is not dependent on women's socio-economic status or where they live.

\section{Competing Interests Statement}

The authors declare that they have no competing or potential conflicts of interest.

\section{References}

Agunbiade, O. M., \& Ogunleye, O. V. (2012). Constraints to exclusive breastfeeding practice among breastfeeding mothers in Southwest Nigeria: implications for scaling up. International Breastfeeding Journal, 7(1), 5. https://doi.org/10.1186/1746-4358-7-5

Ajayi, A. (2012). Essentials of Breastfeeding. A PowerPoint and Paper presented at Lagos State Ministry of Health, 6th September, 2012.

Anaeto, S. G., Onabajo, O. S., \& Osifeso, J. B. (2008). Models and Theories of Mass Communication. Bowie, Maryland: African Renaissance Books Incorporated.

Arnould, E., Price, L., \& Zinkhan, G. (2002). Consumers. New York: McGraw-Hill.

Aryeetey, R. N. O., \& Goh, Y. E. (2013). Duration of exclusive breastfeeding and subsequent child feeding adequacy. Ghana medical journal, 47(1), 24-29. Retrieved from https://www.ajol.info/index.php/gmj/article/view/88765

Baran, S. J., \& Davis, D. K. (2011). Mass communication theory: Foundations, ferment, and future. Boston: Wadsworth Cengage Learning.

Burton, G., Stewart, C., Lavelle, M., Kowaltzke, A., Rayner, P., Wall, P., \& Lacey, N. (2002). More than Meets the Eye: An Introduction to Media Studies (p. 230). Arnold.

Cox, K. N., Giglia, R. C., \& Binns, C. W. (2015). The influence of infant feeding attitudes on breastfeeding duration: evidence from a cohort study in rural Western Australia. International Breastfeeding Journal, 10(1), 25. https://doi.org/10.1186/s13006-015-0048-3

Federal Ministry of Health, FMOH. (2010). National Policy on Infant and Young Child Feeding in Nigeria. Retrieved from http://www.health.gov.ng/doc/IYCFPolicy.pdf.

Fill, C. (2009). Marketing Communication: Interactivity, Communities and Contents. London: FT Prentice Hall

Hawkins, D. I., Best, R. J., \& Coney, K. A. (1995). Consumer Behaviour: Implications for Marketing Strategy .Chicago: Irwin

Hiiraan Online. (1999-2013). Breast feeding is the cheapest and most effective life save in history. Retrieved from http://www).hiiraan.com/news4/2013/Aug/30584/unicef_breastfeeding_is_the_cheapest_and_most_effectiv 
e_life_saver_in_history.aspx

Tichenor, P. J., Donohue, G. A., \& Olien, C. N. (1970). Mass media flow and differential growth in knowledge. Public Opinion Quarterly, 34, 159-170. https://doi.org/10.1086/267786

McQuail, D. (2010). Mass Communication Theory. London: Sage Publications.

Mgongo, M., Mosha, M. V., Uriyo, J.G., Msuya, S. E., \& Stray-Pedersen, B. (2013). Prevalence and predictors of exclusive breastfeeding among women in Kilimanjaro region, Northern Tanzania: a population based cross-sectional study. International Breastfeeding Journal, 8(1), 12. https://doi.org/10.1186/1746-4358-8-12

Moisse, K. (2011). Breastfeeding, What is Best? Retrieved from $\mathrm{http} / /$ abcnews.go.com/Health/wparentingResource/breastfeeding-exclusively-months-best/story?id=12

National Resources Defence Council, NRDC. (2005). Issues: Health Benefits of Breastfeeding NRDC Online Newsletter. Retrieved from http://www.nrdc.org/breastmilk/benefits.asp

Nigerian Institute of Journalism NIJ (1996). Integrated Health and Population Communication Curriculum: A Manual for Teaching and Learning. Lagos: Nigerian Institute of Journalism in Collaboration with John Hopkins University Population Communication Services.

Schiffman, L. G., \& Kanuk, L. L. (2007). Consumer Behaviour. New Jersey: Pearson/Prentice Hall.

Straubhaar, J., \& LaRose, R. (2002). Media Now: Communications Media in the Information Age. Belmont, CA: Wadsworth, Thomson Learning.

Umar, A. S., \& Oche, M. O. (2013). Breastfeeding and Wearing, Practices in an Urban Slum in North Western Nigeria. International Journal of Tropical Disease \& Health, 3(2), 114-125. https://doi.org/10.9734/IJTDH/2013/1337

WHO. (2015). Nutrition: Exclusive Breastfeeding. Retrieved from http://www.who.int/nutrition/topics/exclusive_breastfeeding/en

UNICEF. (2015). Infant and Young Child Feeding Development Agenda. Retrieved from www.unicef.org/nutrition/index-24805.html

UNICEF. (2013). Breastfeeding is the Cheapest and most Effective Life-Saver in History. Retrieved from http://www.unicef.org/media/media_70044.html

UNICEF. (2010). Improving exclusive breastfeeding practices by using communication for development in Infant and Young Child Feeding programmes. New York: UNICEF, 16.

UNICEF. (2006). 1990-2005: Celebrating the Innocenti Declaration on the Protection, Promotion and Support of Breastfeeding Past Achievements, Present Challenges and the Way Forward for Infant and Young Child Feeding. Innocenti Research Centre, Florence, Italy.

Women'shealth.gov. (2011). Your Guide to Breastfeeding for African American Women Breastfeeding. Retrieved from https://www.womenshealth.gov/files/assets/docs/breastfeeding/breastfeedingguide-africanamericanenglish.pdf

\section{Copyrights}

Copyright for this article is retained by the author(s), with first publication rights granted to the journal.

This is an open-access article distributed under the terms and conditions of the Creative Commons Attribution license (http://creativecommons.org/licenses/by/4.0/). 